\title{
Remembering and Forgetting Phantoms of Remembrance: Social Memory and Oblivion in Medieval History after Twenty Years
}

For a long time I have been thinking about and arranging to do something which, with the assistance of God, I now undertake because I do not think it should be delayed: I am reviewing my works-whether books, letters, or treatises-with a kind of judicial severity, and, as it were, with a censor's the pen, I am indicating what displeases me. ${ }^{1}$

As I reflect on my Phantoms of Remembrance ${ }^{2}$ some 22 years after I wrote it, I feel very much as did Augustine of Hippo as he, at a more advanced age, looked back on his own writings with the intention of criticizing his own younger self. I am still satisfied with some of what I wrote. But in many critical ways, the study of medieval memory and oblivion has advanced considerably over the past two decades and it is only right to reflect on areas in which what I wrote then was inadequate or just simply wrong.

When I first began to develop an interest in the history of memory in the 1980s, what Jay Winter has since termed "the memory boom" had not yet begun, and I had only a vague idea of what it was that I hoped to research. ${ }^{3}$ My interest was not in historiography per se, it was not in mnemonics as had been studied for the Renaissance by Frances Yates, ${ }^{4}$ and it was not in the theology of memory in the Augustinian tradition. ${ }^{5}$ My interest was rather drawn to the complex processes of rethinking the past on the part of ordinary clerics and lay persons, less when they were reflecting on memory than when one could observe them in the act of remembering. Having previously written books on the cult of relics ${ }^{6}$ and on Merovingian regional history, ${ }^{7}$ I

\footnotetext{
1 Iam diu est ut facere cogito atque dispono quod nunc adiuuante Domino adgredior, quia differendum esse non arbitror, ut opuscula mea, siue in libris, siue in epistulis, siue in tractatibus, cum quadam iudiciaria seueritate recenseam, et quod me offendit uelut censorio stilo denotem. Augustine, Retractationum libri II, I,1, ed. by Almut Mutzenbecher, in: Corpus Christianorum, Series Latina 57, Turnhout 1984, 5.

2 Patrick J. Geary, Phantoms of Remembrance: Memory and Oblivion at the end of the first Millennium, Princeton 1994.

3 Jay Winter, The Generation of Memory: Reflections on the Memory Boom in Contemporary Historical Studies, in: Bulletin of the German Historical Institute, Washington DC 27 (2000), reprinted in Canadian Military History, 10 (2001), 57-66, Available at: http://scholars.wlu.ca/cmh/vol10/iss3/5. Winter's most significant contribution to the history of memory is his Sites of Memory, Sites of Mourning: The Great War in European Cultural History, Cambridge 1995.

4 Frances Amelia Yates, The art of Memory, London 1966.

5 The philosophical and theological history of memory is the subject of Janet Coleman, Ancient and Medieval Memories: Studies in the Reconstruction of the Past, Cambridge 1992.

6 Patrick J. Geary, Furta Sacra: Thefts of Relics in the Central Middle Ages Princeton 1978. Revised edition 1991.
} 
had been struck by how the sources of early medieval history had been selectively transmitted and, in the process, transformed in the eleventh and twelfth centuries. I spent several summers in the Bibliothèque nationale, Bayerische Staatsbibliothek, the Bibliothèque royale in Brussels, and elsewhere, looking at Carolingian hagiographical manuscripts as well as at later manuscripts that contained Carolingian hagiography. I saw the myriad ways that these Carolingian texts had been recombined, as they were rebound, recopied, and revised in different types of hagiographical and historiographical collections. I wondered about how the very different convoy of these texts in the eleventh and twelfth centuries might have changed not only the way that they were used but also more subtly how they were understood in their new contexts, in contrast to their meanings at the time that they were written.

Working with Merovingian charter evidence led me to similar reflections: In the 1970s I regularly attended the seminars of Georges Duby, who more than anyone else was capable of making charter evidence speak to fundamental issues of society and culture. His interest, of course, was in the great cartularies of Cluny and other monastic houses of the eleventh and twelfth centuries. ${ }^{8}$ But why, of the thousands of documents produced prior to the year thousand, were there so few that were transmitted in these cartularies? Had Viking, Magyar, and Saracen raids really destroyed virtually all of the archives of the great Carolingian monasteries? And why did the cartulary form appear east of the Rhine almost two centuries before it developed in the West? Moreover, the texts that I studied, such as the early eighth century testament of Abbo of Provence, had undergone editing in the process of transmission. What did these changes mean about the relationship between copyists and the past?

I had also spent considerable time in Freiburg with Karl Schmid and his team that at the time included, among others, Gerd Althoff and Dieter Geuenich and in Münster in Joachim Wollasch's Sonderforschungsbereich 7 working with Maria Hillebrandt and Franz Neiske, but also with my dear friend the late Otto Gerhard Oexle, who had recently arrived in Münster from Freiburg. ${ }^{9}$ My interest was to understand the internal logic and significance of Libri memoriales, which was the focus of the Freiburg group, and of necrologies, which was the focus of the Müsteraner. ${ }^{10}$ Why

7 Patrick J. Geary, Aristocracy in Provence: The Rhone Basin at the Dawn of the Carolingian Age. University of Pennsylvania Press, Philadelphia/Stuttgart 1985.

8 Duby's skill at reconstructing a society from charters was most brilliantly demonstrated in his classic La société aux XIe et XIIe siècles dans la region mâconnaise, Paris 1954, but even at the end of his life he continued to meditate on what could and what could not be gleaned from charter evidence, as seen in his L'histoire continue, Paris 1991, esp. 57-70.

9 On the scholarship focused on Libri memoriales, see most recently Dieter Geuenich and Uwe Ludwig. (eds.), Libri Vitae: Gebetsgedenken in der Gesellschaft fdes Frühen Mittelalters, Cologne, Weimar, Vienna 2015. Oexle's pathbreaking studies on memory and many other topics are collected and published in Otto Gerhard Oexle, Die Wirklichkeit und das Wissen: Mittelalterforschung-Historische Kulturwissenschaft-Geschichte und Theorie der historischen Erkenntnis, Göttingen 2011.

10 Die Klostergemeinschaft von Fulda im früheren Mittelalter, ed. by Karl Schmid et al. , 3 vols. in 5, Munich 1978 (Münstersche Mittelalter-Schriften 8). 
did these two different forms of quasi-liturgical commemoration develop as they did? Why did the Liber memorialis tradition disappear while the necrological tradition carried through the Middle Ages and beyond? Since generations of monks recorded in libri memoriales were commemorated only by name, not by date of death, these memorials could not be transferred into necrologies which organized the dead according to the calendar. What then was the effect on monastic communities' ability to remember and to commemorate their dead from this earlier period since they were excluded from the increasingly fundamental form of liturgical commemorative text?

These were the specific professional experiences that turned me toward a history of memory. However there were other considerations that no doubt had a significant influence on my interests. In the 1960s I had studied phenomological existentialism at the Institut supérieur de philosophie at the Université catholique de Louvain and there, through the brilliant teaching of Albert Dondeyne (1901-1985), encountered the work of Maurice Merleau-Ponty (1908-1961). His 1944 Phénoménologie de la perception emphasized the active process of knowledge acquisition and in particular the importance of memory in making intelligible that which is perceived. Indeed, as Merleau-Ponty argued, perception is only possible if that which is perceived can be understood as intelligible, and this intelligibility is possible only through memory. ${ }^{11}$ Thus, far from a passive storehouse or purely receptive faculty, memory must be understood as active and creative.

A final influence was much more personal and familial. In 1988, largely as a favor to my family, I had edited and published the memoirs of my great-greataunt, Céline Frémaux Garcia (1850 - 1935), who lived with her mother and siblings between Union and Confederate lines during the American Civil War. ${ }^{12}$ The cousin who loaned me the manuscript also provided me with access to the extant family papers and other memorabilia that he had inherited from her. As I edited, annotated, and fact-checked this sad account of a young woman growing up amid the horrors of war in a troubled emigrant family in Louisiana, I saw how what she wrote some forty years after the period that she was recording had been filtered by subsequent life experiences. But also, as I examined the photos, books, and other objects that she had kept from her childhood, I could see how these objects had triggered memories, some extraordinarily vivid and passionate, others largely invented, decades later.

All of these professional, educational, and personal experiences pushed me toward a vague concept of writing about memory. But what I was not reading, and should have been, was the growing theoretical literature on memory in historical perspective being produced by Jan and Aleida Assmann, ${ }^{13}$ Mary Carruthers, ${ }^{14}$ and Pierre

11 Maurice Merleau-Ponty, Phénoménologie de la perception, Paris 1945.

12 Céline: Remembering Louisiana, 1850 -1871, ed. by Patrick J. Geary, Athens, Ga. 1987.

13 Especially, Jan Assmann, Das kulturelle Gedächtnis: Schrift, Erinnerung und politische Identität in frühen Hochkulturen, Munich 1992. 
Nora, ${ }^{15}$ works that I only began to read when I was well along in my project. Early on I had engaged with the early theorists of collective memory, especially Maurice Halbwachs, ${ }^{16}$ as well as Frances Yates's 1966 Art of Memory. ${ }^{17}$ Likewise, I had read both in the contemporary experiential psychology of memory that had developed from the pioneering work of Hermann Ebbinghaus ${ }^{18}$ and that of the social psychologist F. C. Bartlett. ${ }^{19}$ However, I should have spent more time and attention with the work of contemporary historians and theorists who had already blazed a trail for understanding how memory works in human society.

Turning now to this scholarship today, I find particularly helpful Jan Assmann's development of the concept of the social construction of the past, a concept that he freely admits to having taken over from Maurice Halbwachs, but that he developed further. ${ }^{20}$ Assmann emphasized the past as a social construction, not a natural growth. Likewise, his distinction between communicative and cultural memory, the former histories of individuals, informal, organic, of short duration, and transmitted by contemporary witnesses; the latter timeless, formal, fixed symbolically, belonging outside normal time, and transmitted by specialized bearers of tradition, is likewise a powerful way of thinking about two poles of memory cultures. ${ }^{21}$

What I find less than satisfactory in much that has been written before and since my own efforts is the way that many theorists posit, or better avoid discussing, the process that moves between communicative and cultural memory, thus creating collective or social memory.

A statement by Aleida Assmann is both typical and, I think, problematic. She wrote:

Cultural functional memory is connected with individual persons who re-embody it as its bearers and addressees. Collective agents such as states or nations create for themselves a functional identity memory through which they adapt a certain version of the past and define their goals for the future. ${ }^{22}$

14 Mary Carruthers, The book of memory: a study of memory in medieval culture. Cambridge 1990; and an edited volume with Jan M. Ziolkowski, The medieval craft of memory: an anthology of texts and pictures, Philadelphia 2002.

15 Especially important was the collection edited by Pierre Nora, Les Lieux de mémoire, 3 vol. in 7, Paris 1984-1986.

16 Maurice Halbwachs, La mémoire collective, ed. by Gérard Namer and Marie Jaisson, Paris 1997; and La topographie légendaire des évangiles en terre sainte; étude de mémoire collective, $2^{\text {nd }}$ ed., Paris 1971.

17 Yates, The art of memory (note 4).

18 Hermann Ebbinghaus, Über das Gedächtnis. Untersuchungen zur experimentellen Psychologie, Leipzig 1885.

19 F. C. Bartlett, Remembering: A Study in Experimental and Social Psychology, Cambridge 1932.

20 Jan Assmann, Das kulturelle Gedächnis (note 13), 34-48.

21 Jan Assmann, Das kulturelle Gedächtnis (note 13), 48-59.

22 Aleida Assmann, Cultural Memory and Western Civilization: Functions, Media, Archives, Cambridge 2011, 127-128. 
Such a formulation makes abstract collectivities such as states literally agents, subjects that act with intention and purpose every bit as much as an individual person. It suggests that these collectivities have agency and rationality, and ignores the reality that states or nations do not create anything for themselves. Texts are written by individual people and while they may purport to record collective memories, they always necessarily reflect what the individual, perhaps in collaboration with likeminded associates, wants the collective memory to be. They are never the simple representation of the memory of a whole community or society. Here, Rosamond McKitterick's reflections on "collective memory" in her 2004 History and Memory in the Carolingian World are particularly insightful. ${ }^{23}$ Discussing the Royal Frankish Annales' account of the downfall of Tassilo in 788, which claims that those present "remembered his earlier evil deeds," she asks: "In what sense was the memory described in the annals one that was part of collective memory? Who is included in the notion of collective memory? Is the memory based on knowledge of the annals or a real memory among those at Ingelheim in 788...?"24 Rather than taking such texts at their word, we must remember that individual humans or groups of humans, claiming, to act on behalf of a larger collectivity, generate versions of the past by which they hope to advance their future goals. Certainly, it is not always possible, given our sources, to know who these individuals are. However, to assume that the "collective memory" is the product of collective agents such as states and not the product of cultural brokers, propagandists, ideologues, or the like, misses a key factor in the historical process, that by which individuals are able to impose their versions of the past on others.

A second area that I find a gap between theoretical approaches and historical issues is the much-discussed field of brain science and the study of neural networks. One cannot doubt that important advances in neurological sciences are contributing to the understanding of brain functions including memory, forgetting, and cognition. However again I find the gap between the chemical and laboratory studies of brain function and the historical analysis of memory, as in Johannes Fried's Der Schleier der Erinnerung, unclear. ${ }^{25}$ His analyses of the weakness and problematic nature of traditional historical sources, largely corresponds to what generations of historians have recognized as the challenge of textual critical history-I do not see how discussions of brain chemistry actually add to this discussion. This is why, in contradiction to Fried's statement that I and others have ignored cognitive science in our study of memory, while not ignoring either neuroscience or experimental psychology, I have concentrated not on formal neurological science but rather the work of scientists in

23 Rosamond McKitterick, History and Memory in the Carolingian World, Cambridge 2004.

24 McKitterick, History and Memory (note 21), 4-5.

25 Johannes Fried, Der Schleier der Erinnerung: Grundzüge einer historischen Memorik, Munich 2004. 
the tradition of F. C. Bartlett, who concentrate on the social and cultural dynamics of memory. ${ }^{26}$

A third area of theoretical debate that I have found less than useful in my own work subsequent to the publication of Phantoms of Remembrance is the dichotomy between orality and literacy. This distinction, which is key in the work of ancient historians such as Jan Assmann and draws considerably on the theoretical work of Jack Goody, ${ }^{27}$ initially attracted the attention of medievalists, including Michael Clanchy and Brian Stock, among others. However, both Clanchy and Stock have come to realize that whatever its merits for understanding ancient cultures, orality and literacy work quite differently in medieval societies. In the second edition of his From Memory to Written Record, Clanchy largely abandoned his teleological image of the replacement of oral memory by documentation..$^{28}$ In his Listening for the Text, Brian Stock fruitfully develops what he terms the "weak thesis" of orality and literacy that, in his words, "attempts to account for the interaction of the oral and the written after the initial steps taken. It assumes that a knowledge of writing is not completely new." ${ }^{29}$ Certainly, such a view is much more in keeping with our understanding, developed in the English speaking scholarship by Rosamond McKitterick, of the centrality of literacy in early medieval societies. ${ }^{30}$ It is unfortunate that McKitterick's insights took so long to penetrate the scholarship on memory systems.

My interest in Phantoms was never to evaluate the quality of information transmitted from the past to the eleventh century. Nor was it to look at how eleventh-century historiography might have suppressed, restructured, or reinterpreted the past. My focus was rather on those modes of enregistering and transmitting, the processes of mediation itself, Medialität, and the effects that these systems of storage and retrieval had on what would or would not be transmitted. ${ }^{31}$ Thus, while much of what has been written subsequently has dealt with narrative sources, with the processes of writing and rewriting chronicles, annals, and hagiography in order to construct a meaningful past, this kind of more traditional historiography has never been my primary focus. My interest was from the start the comparison of different storage and retrieval systems in the early and later periods, the ways that these systems shaped and even created memory, and the effects of changing from one system to another.

26 Fried, Der Schleier (note 25), 77-78.

27 Especially, Jack Goody (eds.), Literacy in traditional societies, Cambridge 1968, and The Logic of Writing and the Organization of Society, Cambridge 1986.

28 Michael Clanchy, From memory to written record, England 1066-1307, $2^{\text {nd }}$ ed. London 1993.

29 Brian Stock, Listening for the Text: On the Uses of the Past, Philadelphia 1996, 5-6.

30 Especially Rosamond McKitterick, The Carolingians and the Written Word, Cambridge 1989, and Rosamond McKitterick (ed.), The Uses of Literacy in Early Mediaeval Europe, Cambridge 1990.

31 On Medialität in particular see Christian Kiening, Fülle und Mangel Medialität im Mittelalter, Zurich 2016 and Modelle des Medialen im Mittelalter, Christian Kiening and Martina Stercken (eds.), Das Mittelalter: Perspektiven mediävistischer Forschung 15,2 (2010). 
Generally, the broad areas I attempted to examine from the perspective of memory systems were family memory; archival memory; institutional memory; and political memory.

Concerning the family memory, I emphasized the role of religious institutions in preserving and thus structuring kinship groups' access to their ancestors. In light of the recent, revisionist work of Hans Hummer, I should have gone still further, recognizing that to a considerable extent religious institutions did not simply preserve and shape family memory, they created these very families through their religious ideology and through their selective preservation of the memoria of benefactors. ${ }^{32}$

I also argued that the eleventh century saw a conflict between the continuation of the memoria of dead members of families and lineages between the women relatives who were those traditionally responsible for memoria of the dead and organized male monastic communities such as the Cluniacs who promised a more secure and efficacious liturgical memory. Since 1994 much has been written on memory and gender and I believe that we have a much more nuanced understanding of the roles of men and women in family memory. Elisabeth van Houts was a pioneer in this field, exploring the question from a wider perspective than mine and placing some of my own observations and hypotheses in a more convincing context. ${ }^{33}$ In particular, she has shown that rather than understanding female familial memory and male monastic memory as competitive, their roles were complementary and even collaborative. While she agrees that the evidence of women's responsibility for family memory is most evident in the tenth century, she demonstrates that the disappearance of women as repositories and transmitters of family memory is more related to the ideology of authority than to actual practice. With rare exceptions, male authors do not credit women as the sources of information about the past. Nevertheless, she was able to adduce numerous cases in which women must have been the key figures in the recollection and transmission of family memory to future generations. Moreover, they were often the patrons of the male monastic institutions in which liturgical memory of these same individuals was preserved.

Still, while I must adjust the overall image of women as rememberers that I penned in 1993, I continue to think that my approach, namely to compare not the role of women in memory east and west of the Rhine but rather the representation of women's role in memory, was a valid one. We must be careful not simply to mine narrative sources, whether hagiographical, historiographical, or archival, for anecdotes about women and memory. Rather we must compare different traditions of representing these roles, and ask why representations of the same events should so differ. I continue to believe that regular monastic communities of men such as that of the ecclesia Cluniacensis represented women's role in the preservation of memory in ways that

32 Hans Hummer, Visions of Kinship in Early Medieval Europe, Oxford, 2018. I am grateful to Professor Hummer for allowing me to read his important book prior to publication.

33 Elisabeth van Houts, Memory and gender in medieval Europe, 900 -1200, Basingstoke 1999. 
were subtly different from the representation of these same roles by secular clergy and especially by women themselves. However I take van Houts's criticism as valid that in spite of how the gendered nature of the memory of the dead may be presented, the actual process was more complementary than antagonistic.

My attempts to understand archival memory is perhaps the aspect of my work that has solicited the most productive criticism. Much of this discussion has been focused on the precocious origins of cartularies in the east and their tardy appearance in the west. I argued that the preparation of a cartulary was no mere gathering and copying of an institution's archive, a transparent view of whatever single leaf documents might have been available at the moment of compilation. Rather, I argued that cartularies were intentionally constructed and that the selection of documents and their organization were meaningful operations. Initially this premise was rejected by some French scholars who believed that cartularies simply reproduced the content of a specific archive without exercising editorial intention either in selection or in organization. ${ }^{34}$ However, by and large few doubt today that cartularies are anything but transparent windows into the archives of an institution at the time that they were created. Much more problematic, however, were my attempts to explain the origins of cartularies and the reasons that they first appeared in the East and then largely disappeared in these regions at the same time that they began to be common in the West. Here I think that there is much to revise.

The most basic revision is the actual chronology and geography of their origins. I believed that the first cartulary was that of Fulda, created ca. 828 and tied to the reforms instituted in that monastery by Hrabanus Maurus, ${ }^{35}$ while in Bavaria cartularies or fragments of cartularies from Regensburg, ${ }^{36}$ Mondsee, ${ }^{37} \mathrm{Passau},{ }^{38}$ and Freising $^{39}$ survive from the 820 s to 840 s. I saw these Bavarian examples as developments from the dossiers developed in Salzburg as the Notitia Arnonis and

34 Laurent Morelle, Histoire et archives vers l'an mil: une nouvelle 'mutation'?, in: Histoire et archives, 3 (1998), 119-141.

35 Marburg, Fulda Kopialbuch, Hessisches Staatsarchiv, Marburg, K 424. Urkundenbuch des Klosters Fulda, ed. by Edmund E. Stengel, 2 vols., Marburg 1956.

36 Munich, Bayerische Haputstaatsarchiv, St. Emmeram Kl. Lit. 5 11/2 (Anamot’s Codex traditionum); St. Emmeram Kl Lit. 5 1/4b (fragments of St. Emmeram Traditionsbücher), Die Traditionen des Hochstifts Regensburg und des Klosters S. Emmeram, ed. by Josef Widemann, Quellen und Erörterungen zur bayerischen und deutschen Geschichte n.f. 8, Munich 1943.

37 Vienna, Haus-, Hof- und Staatsarchiv Wien Blau 70, Das älteste Traditionsbuch des Klosters Mondsee, ed. by Gebhard Rath and Erich Reiter, Linz 1989.

38 Munich, Bayerisches Hauptstaatsarchiv, Passau Lit. 1, Die Traditionen des Hochstifts Passau, ed. by Max Heuwieser, Munich 1930 (Quellen und Erörterungen zur bayerischen Geschichte N.F. 6).

39 Munich, Bayerisches Hauptstaatsarchiv, Hochstift Freising Lit. 3a, Die Traditionen des Hochstifts Freising, ed. by Theodor Bitterauf, Munich 1905-09 (Quellen und Erörterungen zur bayerischen und deutschen Geschichte N.F. 4-5). 
the Breves Notitiae ${ }^{40}$ and thought that these early cartularies were, like the Salzburg documents, intended to establish rights to property that were thrown into question by the transition from Agilolfing to Carolingian control. More recently, Constance Bouchard has suggested that the cartulary tradition originated in the Rhineland at Fulda, Wissembourg, and Lorsch, apparently ignoring the Bavarian tradition. ${ }^{41}$ She saw in the pre-history of the cartulary not the Salzburg documents but the Codex Carolinus, a volume compiled in 791 by the royal chancery containing ninety-nine papal letters addressed to the Carolingian rulers between the years 739 and 791 . While the contents were radically different (papal letters rather than private charters), she saw in the organization a similarity that suggested that the Carolingian collection might have served as a model for later Rhineland cartularies.

It appears however that we were both wrong. I had completely overlooked what is by far the oldest cartulary fragment, that of one prepared in Chur around the year 800. ${ }^{42}$ Peter Erhart, who has studied these fragments, points out that the surviving bifolium, which contain six private charters, was written by a scribe who was active at Chur during the episcopacy of Bishop Remedius, the last Chur bishop to hold both the highest ecclesiastical office and, as praesides Rhaetiae, the highest civil position..$^{43}$ Remedius's chronology is not exact, with the dates of $780-800$ for the beginning of his episcopacy and 806 as the date when Charlemagne ended the union of secular and ecclesiastical office. This may have corresponded with his death, although he may have continued as bishop until ca. 820. In any case, the cartulary he composed is much earlier than either that of Fulda or those from Bavaria. Unlike the rather pedestrian Fulda cartulary, the Chur document is carefully and elegantly prepared in a clear Caroline minuscule. Each charter begins with a title in majuscule that indicates the name of the donor. The two documents on the intact page indicate contemporary numbering in the margin. Not enough of the cartulary has survived to determine its principle of organization, but the rubrics focus on the donor rather than the property donated. Josef Ackermann has suggested that the cartulary might possibly have been prepared during or immediately after the division imposed

\footnotetext{
40 Notitia Arnonis und Breves Notitiae: Die Salzburger Güterverzeichnisse aus der Zeit um 800: Sprachlich-historische Einleitung, Text und Übersetzung, ed. by Fritz Lošek, in: Quellen zur Salzburger Frühgeschichte, ed. by Herwig Wolfram, Vienna 2006 (Veröffentlichungen des Instituts für Österreichische Geschichtsforschung 44; Mitteilungen der Gesellschaft für Salzburger Landeskunde. Ergänzungsband 22), 9-178.

41 Constance Bouchard, Rewriting Saints and Ancestors: Memory and Forgetting in France, $500-$ 1200, Philadelphia 2015, 11.

42 Josef Ackermann, Fragmente frühmittelalterlicher Handschriften im Klosterarchiv Müstair, in: Schrift, Schriftgebrauch und Textsorten im frühmittelalterlichen Churrätien: Vorträge des internationalen Kolloquiums vom 18. bis 20. Mai 2006 im Rätischen Museum in Chur, ed. by Heidi Eisenhut, Karin Fuchs, Martin Hannes Graf, and Hannes Steiner, Basel 2008, 294-306, III Chartular, 300 - 304. 43 Peter Erhart, Erratische Blöcke am Alpennordrand? Die rätischen Urkunden und ihre Überlieferung, in: Die Privaturkunden der Karolingerzeit, ed. by Peter Erhart, Karl Heidecker, and Bernhard Zeller, Zurich 2009, 161-171.
} 
by Charlemagne on the bishop of Chur, a division that according to Bishop Remedius's successor Victor III in 823 cost the bishopric more than 200 churches, ${ }^{44}$ but this is not at all certain. What is certain is that the arguments that I and others set out to explain the appearance of this fundamental type of memorial book must be reconsidered. However, as in the Bavarian cases, the disruptions of the Carolingian takeover and reorganization of ecclesiastical property and power may somehow lie behind the decision to copy private charters into these codices.

My reflections on institutional memory, in particular those as recorded at Benediktbeuern and Novalesa, were the sections most influenced by my edition of my great-great aunt's memoires. This is because in both of these institutions, as in my family's home in New Orleans, the authors were surrounded by and deeply influenced by fragments of other texts, tombs, physical objects, and other realia that they used as objects of memory as they constructed corporate pasts. These objects and fragments did not in themselves constitute a narrative, nor did they hold an intrinsic meaning. However, as tangible connections to a distant past, they became both anchors and guides in the construction of such a narrative, a narrative ultimately intended for the present and the future. Here again I have learned a great deal from subsequent scholarship on the role of the built environment in structuring an understanding of the past. I would reference in particular the extraordinary work of Teemu Immonen on the construction of identity at Monte Cassino in the eleventh century. Drawing on fragmentary manuscript evidence, poorly understood texts, fragments of liturgical objects, and regional churches, he has created a very probable reconstruction of the fresco cycles in the long-vanished church of Monte Cassino dedicated in $1071 .^{45}$ But as significant as his extraordinary achievement of detective work and imagination certainly is, even more significant is the way that he elucidated how the different registers of images, one the life of Benedict, another biblical history, and a third the life of Christ, provided the members of the community material for meditation. This meditation moved the mind from one register to another, bringing the remembered history of Benedictine monasticism into salvation history and into the monks' own present identity.

Immonen's study is but one of a growing literature on sacred space and sacred time and their influence on the communities that inhabit it. Equally important in recent years have been the reflection on other ways that the past is sacralized but also structured. A key study is Jean-Claude Schmitt's magisterial Les rythmes au Moyen Âge, that reflects on the rhythms of time past, the influence of liturgy and especially biblical language in the denomination of durations within the unrolling of history. ${ }^{46}$ Schmitt is particularly sensitive to the special representations of past time and its possible divisions, represented in diagrammatic forms such as that of a rotula, a lab-

44 Ackermann, Fragmente (note 42), 304.

45 Teemu Immonen, Building the Cassinese Monastic Identity: A Reconstruction of the Fresco Program of the Desiderian Basilica (1071), Mustasaari 2012.

46 Jean-Claude Schmitt, Les rythmes du Moyen Âge, Paris 2016, esp. 475-530. 
yrinth, chain, or tree, but also in monumental form such as the bronze column of Saint Michel of Hildesheim or the frescos of Monte Cassino.

The fourth aspect of memory that I attempted to examine was that of rulers, elites, and princes, political memory as I termed it, although the designation is certainly anachronistic. This type of memory has been the most studied before and since, particularly by many of the people participating in this conference. Therefore I need not point out how the extraordinary work of the Vienna and Cambridge schools of analysis have perfected the study of the ideological manipulation of the past. Beginning with Walter Pohl's 2001 Werkstätte der Erinnerung and Rosamond McKitterick's 2004 History and Memory in the Carolingian World, and culminating most recently with Helmut Reimitz's magisterial History, Frankish Identity and the Framing of Western Identity. ${ }^{47}$ These studies make it abundantly clear that what I mistakenly called "political memory" is much more: it is really the heart of the ideological construction of corporate identity - identity understood as institutional, ethnic, religious, or regional, which was constantly disputed and challenged through rewritings of narrative and normative texts.

The area of research that most interested me, however, is one that has been relatively less studied, and that is oblivion. Of course, it is hard to study what is not there: this was clear from the start. Oblivion is close to Mary Carruther's concept of "Purged Memory," or Janet Coleman's "blanched memory". Wim Verbaal has particularly developed the investigation of such purged memory in his study of Bernard of Clairvaux. He examines how Bernard understood oblivion both as the result of sin, by which mankind has forgotten its proper relationship to God, and also as a positive virtue, by which individual memories are replaced by memories of God. ${ }^{48}$ Bernard urges his monks to forget their past and to forget themselves, to become the young girl, the adulescentula of the Song of Songs.

My own interest, of course, is more in the social than the theological aspects of purged memory, and here I have found Vincent Challet's essay on Peasants' revolts memories in the rich collection edited by Lucie Doležalová particularly insightful. Working with the vastly more abundant sources of the late Middle Ages, he explores specific measures taken by royal or princely authorities to impose a damnatio memoriae on medieval rebellions. These measures included providing new, negative labels for rebels, coupled granting grace to rebels with an obligation of maintaining silence

47 Walter Pohl, Werkstätte der Erinnerung: Montecassino und die Gestaltung der langobardischen Vergangenheit, Vienna 2001 (Mitteilungen des Instituts für Österreichische Geschichtsforschung. Ergänzungsbände 39); McKitterick, History and Memory (note 23); Helmut Reimitz, History, Frankish Identity and the Framing of Western Ethnicity, 550-850, Cambridge 2015. One should also mention the collected volume, The Uses of the Past in the Early Middle Ages, ed. by Yitzhak Hen and Matthew Innes, Cambridge 2000.

48 Wim Verbaal, Bernard of Clairvaux's School of Oblivion, in: Negotiating Heritage: Memories of the Middle Ages, ed. by Mette B. Bruun and Stephanie Glaser, Ritus et Artes: Traditions and Transformations, 4, Turnhout 2008, 221-237, citing Coleman and Carruthers, 222 note 3. 
about their deeds, and even banning words and phrases that might call to mind unsuccessful rebel groups. At the same time, no less than Bernard of Clairvaux, they sought to replace such memories with new ones: to consign to oblivion the ideological causes of revolts while nourishing stories of rape, murder, and torture by peasant rebels. But Challet goes on to suggest that purged memory was only partially successful and such efforts produced in reaction what he calls hidden memory or insurgent memory - made of "trails, passive resistance, and, eventually calls to arms." of course, by its very nature "hidden memory" cannot be fully recovered any more than the oblivion about which I wrote two decades ago. However if one reads our sources across the grain, tantalizing evidence emerges. Challet mentions, for example, the account in Suplicius Severus's Vita Sancti Martini of a popular cult at the grave of unknown Christian martyrs. The saint prayed at the grave and a ghost appeared revealing that he was actually a bandit executed for his crimes. ${ }^{49}$ Perhaps, Challet suggests, the Vita labeled as bandits those known otherwise as Bagaudes. This is speculation, but should we not perhaps look for other evidence of erasures and rewritings in our texts, not simply within the closed world of historiography but also for evidence of attempts to destroy memory and thus identity, substituting alternative memories and hence identities to wider segments of society? Our focus again would be not so much on the erasures and alternatives themselves as the technologies of memory purging, those political and social measures aimed at enforcing oblivion. With Challet, one might begin with the suppression and substitution of names, but also with narratives, rituals, and commemorations that compel people to accept a particular version of the past and in so doing, to adhere to a particular identity in the present. These strategies of erasure in the fabric of peoples' lives were no less real than the physical erasures, destructions, and reuses I described in the cartularies and charter collections of the ninth and tenth centuries. All were perpetrated to silence or, as my hero Arnold of Regensburg suggested, to discard or bury that which did not conform to the proper order of things. ${ }^{50}$

Thus, two decades after my attempt to write about memory and oblivion, I continue to be drawn more to the latter than to the former: it is a great thing to study, as many fine scholars have done, how the past was recorded and transformed. But if I had it to do over, I would concentrate in attempting to recover not so much the new past that was thereby created, but the old past that was, with only partial success, discarded or buried, but which nevertheless continued to haunt the present as phantoms.

49 Vincent Challet, Peasants' Revolts Memories: Damnatio memoriae or Hidden Memories?, in: The Making of Memory in the Middle Ages, ed. by Luvie Doležalová, Leiden 2010, 397-414; 408, citing Jean-Claude Schmitt, Le Saint Lévrier: Guinefort, guérisseur d'enfants depuis le XIIIe siècle, Paris 1979, 39-40.

50 PL 141:992. See Geary, Phantoms (note 2), 165-166. 